\title{
A Heterogeneous Study of the Effect of Housing Price on Family Consumption in China
}

\author{
Shutong $\mathrm{Wu}^{*}$, Yonghuan Chen \\ School of Economics, Jinan University, Guangzhou, China \\ Email:*1245526243@qq.com
}

How to cite this paper: $\mathrm{Wu}, \mathrm{S}$. T., \& Chen, Y. H. (2020). A Heterogeneous Study of the Effect of Housing Price on Family Consumption in China. American Journal of Industrial and Business Management, 10, 1317-1335.

https://doi.org/10.4236/ajibm.2020.108087

Received: July 10, 2020

Accepted: August 2, 2020

Published: August 5, 2020

Copyright $\odot 2020$ by author(s) and Scientific Research Publishing Inc. This work is licensed under the Creative Commons Attribution International License (CC BY 4.0).

http://creativecommons.org/licenses/by/4.0/

\begin{abstract}
Based on the fixed-effect model, with a five-period unbalanced panel data from China Family Panel Studies (CFPS) in 2010, 2012, 2014, 2016 and 2018, this paper studies the effect and the transmitting channel of housing price on consumption. The results show that the effect of housing prices on the consumption of households is significantly positive and the rise of housing price has a stronger effect on the promotion of basic consumption. Further analysis of the differences shows that house prices mainly affect the consumption of high-income families, young and middle-aged families, families with multiple suites, and households in the eastern and central regions. In addition, the intermediary effect test shows that the impact of house prices on consumption is partially transmitted through property income.
\end{abstract}

\section{Keywords}

Housing Price, Household Consumption, Property Income, Fixed Effect Model

\section{Introduction}

Since the housing system reform in 1998, the housing in various provinces and cities in China has gradually stepped into the era of monetization, commercialization and marketization. The rapid development of the real estate market has driven the growth of the local economy and affected every family in China. The most obvious phenomenon is the increasing proportion of real estate wealth in household assets. For example, in 2013, housing assets accounted for $68.3 \%$ of total household assets, but in 2015 it reached $70.1 \%$. The change of housing price means the change of household wealth, which affects household consumption. Therefore, to explore the different influence and transmission mechanism of housing price changes on household consumption is not only helpful for the 
government to formulate reasonable housing policies, but also helpful for the promotion of housing price on household consumption.

Scholars at home and abroad have failed to agree on the effect of housing price on household consumption. Some scholars believe that the rise of housing prices can significantly promote household consumption. Karl et al. (2012) adopted the quarterly data of 28 years since 1975 in the United States, and the empirical results showed that changes in real estate wealth had a significant impact on household consumption expenditure. Thus, the real estate wealth effect was significant. Barrell et al. (2015) analyzed the quarterly data from 1972 to 2012 in the UK from the perspective of empirical test, and found that the wealth effect of real estate was significant in the long run. Li \& Zang (2015) divided consumption into non-durable goods consumption and durable goods consumption. Using the inter-provincial panel data for the eight years from 2004, it was found that the rise in real estate prices significantly promoted the consumption of durable consumer goods. But it had the opposite inhibitory effect on nondurable consumer goods. The wealth effect that promotes consumption is presented.

Some scholars believe that rising housing prices will depress household consumption. Gao \& Zhou (2013) used the macro data of 29 cities in China from 2001 to construct the dynamic panel model for research, and concluded that the fluctuation of housing price rise and fall presented negative correlation to household consumption after 2005 in China. That is to say that housing price presented obvious crowding out effect on household consumption. Hu \& Yuan (2017) extended the data from 1998 to 2011. The dynamic local equilibrium model they constructed estimated the panel data, and found that the continuously rising real estate price formed a significant crowding out on household consumption.

Some scholars also believe that housing prices have heterogeneous effects on household consumption. According to the life-cycle-lasting income theory, Bhatia \& Mitchell (2015) selected sample data from the Canadian Survey of Household Spending (SHS) from 2000 to 2006, constructed the consumption function model using Hedonic regression method, and found that the marginal consumption tendency of young households is only half that of old households. Households with mortgages have a lower marginal propensity to consume than households without mortgages. Li (2015) studied the relationship between housing prices and consumption stratification using the micro panel data and found that housing prices has promoting effect on residents' consumption. But the role has the difference between the residents of different income. Among them, the consumption of high-income residents has not changed because of rising house prices. The middle-income group has a significant wealth effect when it increases short-term consumption, while the low-income group has a short-term consumption that shows a crowding out effect. The overall social effect is the wealth effect. Wang (2016) used data from the China Family Panel 
Studies (CFPS) in 2010, and based on the input-output price model, empirically analyzed the impact of house price fluctuations on household consumption in 25 provinces in China. They classified consumption into three types: survival consumption demand, enjoyment consumption demand and development consumption demand. Among them, fluctuations in house prices have promoted basic survival consumption, while inhibiting enjoyment consumption and developmental consumption. Zhang \& Sun (2019) used the macro and micro data of 136 prefecture-level cities in China from 2001 to 2012 to observe the impact of housing price fluctuations on residents' commodity demand from the perspective of tariff transmission. They found that in the areas with high housing prices, due to the obstruction of the tariff transmission mechanism, rising housing prices have little effect on consumption, and the transmission effect of tariffs shows differences in different cities.

Overall, domestic and foreign scholars' studies on how housing prices affect consumption mostly use national or transnational macro data for empirical analysis, but seldom analyze from the perspective of micro households. When scholars study the effect of housing price on household consumption, they mostly study its transmission channel from theoretical analysis, but rarely use empirical analysis to study its intermediary variable. This article selects the unbalanced panel data of five periods from 2010 to 2018 in CFPS. First, it empirically studies the overall effect of house prices on consumption and the effects of different consumption levels. Then the differences in household income, age of head of household, number of houses and regions were analyzed. Finally, an intermediary effect model is constructed, and it is tested that the impact of house prices on consumption is partly through the transmission of property income. Therefore, this article makes up for the shortcomings of previous research and has practical significance.

\section{The Effect Mechanism and Research Hypothesis}

The impact of housing price on household consumption is mainly realized through the following three channels. 1) Direct wealth effect. When house prices rise, the housing value, the level of wealth and the consumption will increase accordingly. Especially for families with multiple suites, based on meeting their housing needs, they can obtain direct wealth effects by renting, selling, or realizing excess housing. 2) Optimistic expectation effect. When house prices rise, households' expectations of wealth and the economy are more optimistic, making them more willing to spend more, even if their real incomes do not rise significantly. For homeowners, they will form an optimistic expectation of the future appreciation of housing assets, thus increasing household consumption expenditure. For households without homes, they also form optimistic expectations of better economic conditions overall, reducing precautionary savings and boosting consumer spending. 3) Liquidity constraint effect. When the housing price rises, for the homeowners, they can use the credit market to mortgage their 
housing assets to solve the problem of liquidity constraint. Currently, the rising housing price is conducive to increase the loan amount, thus promoting the consumption of the homeowners. For families without a house, as the rent of the house increases, the rental cost of the house and the liquidity constraint increases, so consumption expenditure will decrease.

According to the above theoretical analysis, this article proposes H1: Housing price has a significant positive effect on household consumption. To verify this hypothesis, this paper uses housing prices as the core independent variable, takes total household consumption, basic consumption, and high-level consumption as the core dependent variables respectively, and observes the elasticity coefficient of housing price to consumption. If the elastic coefficient is significantly positive, then the hypothesis 1 holds.

The main factors influencing the difference of housing price on household consumption include the family income, the age of household head, the number of houses and the region. 1) Family income. For high-income families, they have met the basic housing demand. When the housing price rises, the overall wealth level of the family will be improved through direct wealth effect, liquidity constraint effect, mortgage loan or sale of real estate, etc., thus effectively increasing consumption expenditure. For low-income families, when the housing price rises, under the influence of the precautionary savings effect, even though there are effects of the wealth effect of housing price and liquidity constraint effect, the effect of the rising housing price on household consumption may not be significant. 2) Age of the head of household. In the study of inter-temporal consumption, the traditional life cycle theory believes that a cycle refers to the life of a person or a family, and studies the consumption smoothness of the life of a person or a family on this basis. However, China's family consumption is not only within a family of one generation, but often as a cycle of two or three generations of family consumption. This is because, under the influence of traditional Chinese family culture, most of the elderly will provide financial support for their children to buy a house, and the children will be obliged to take care of the elderly accordingly. Currently, household consumption is smooth between different generations rather than within one generation. So, when house prices go up, young people spend more. The middle-aged have a strong precautionary saving motive, and the consumption increase is less than that of the young. The elderly is reluctant to realize their housing assets for the sake of their children's housing, and the impact of rising housing prices on the elderly is not obvious. 3) Number of houses. The probability of a one-suite family mortgaging or selling their only home is very low, so rising prices have less impact on the consumption of one-suite families. However, multi-suite families can adjust their preventive savings more flexibly and realize the value of their housing assets in time. Therefore, the rise of housing price has a stronger positive effect on the consumption of multi-suite families. Many scholars' studies also support this view. Gan (2010) believes that families with multiple apartments have a higher con- 
sumption tendency. 4) Region. China's regional development is unbalanced. The central and eastern regions have relatively developed economies, well-developed financial markets and real estate market systems, and high-income levels. Residents are less affected by liquidity constraints and preventive savings effects. So, this article speculates that the wealth effect of house prices should be stronger. Yi et al. (2011) argued that the western China has relatively underdeveloped economy and low income. The financial market, housing market and social security system needed to be improved in western regions. These reasons strengthened the impact of liquidity constraint and precautionary savings effect, so the wealth effect of housing price should not be significant.

According to the above theoretical analysis, this article proposes H2: For different household income, ages of head of household, numbers of houses and regions, the effect of housing price on household consumption is different. In order to verify this hypothesis, this article groups the sample data according to household income, ages of head of household, numbers of houses and regions, and observes the difference in elasticity coefficient of house prices to consumption in different groups. If the significance and value of the elastic coefficient are different in different groups, then the hypothesis 2 holds.

The fluctuation of house price may indirectly affect household consumption through the change of property income. 1) When the housing price rises, the family property income will increase. First, rising house prices have driven up the return on assets, and homeowners can gain from rising rents. Secondly, the fluctuation of housing price increases the income of households from buying and selling housing assets. When the housing price rises rapidly, the income of households from the real estate market also increases rapidly; when the housing price stabilizes or even falls, the income of households from buying and selling housing will also decrease. Finally, fluctuations in house prices have affected the ability and confidence of households to increase their value. When house prices rise, household wealth levels rise, which makes households' ability to obtain more bank loans through mortgaged housing assets significantly increase. At the same time, homeowners are more confident to hold more assets, which will increase their future property income. According to the above analysis, there is a positive influence between house price and household property income. 2) The increase of property income will increase household consumption. According to western economic theory, consumption is a function of income, while property income is an important part of family income. The increase of property income increases family income and promotes family consumption under the influence of wealth effect. In the life cycle theory, the consumption function is composed of property income and labor income, so the consumption will increase with the increase of property income. So that property income is positively correlated with household consumption expenditure. When the income from rent and deposit interest increase, household consumption expenditure would also increase.

According to the above theoretical analysis, this article proposes H3: property 
income is the intermediary variable of housing price affecting consumption. In order to verify this hypothesis, this article uses property income as the mediating variable of the impact of housing prices on consumption, and conducts a mediating effect test. If the elasticity coefficients of house prices and property income are significantly positive, and the coefficient of house prices decreases, then hypothesis 3 holds.

\section{Model Setting, Variables and Sample Selection}

\subsection{Model Setting}

In order to verify the effect of the housing price on the household consumption, this paper constructs the following model:

$$
\mathrm{LnC}_{i, t}=\beta_{0}+\beta_{1} \mathrm{LnHP}_{i, t}+\beta_{2} \text { LnIncome }_{i, t}+\sum \beta_{\mathrm{k}} X_{k, i, t}+u_{i}+v_{t}+\varepsilon_{i, t}
$$

The dependent variable $\mathrm{C}_{i, t}$ represents the consumption of the $\mathrm{i}$-th household in the $\mathrm{t}$-year. The independent variable HP represents housing price. The control variables Income and $X$ represent respectively family income and the microscopic characteristic variables of the household and head of the household. The variables $u_{i}$ and $v_{t}$ represent respectively the individual fixed effect, and the year fixed effect to control the time effect that can affect all individuals.

\subsection{Variables}

First, the dependent variable is household consumption, specifically including total consumption (C), basic consumption ( $\mathrm{Nec}$ ) and high-level commodity consumption (Dev).

The consumption expenditure data in the CFPS database includes the following eight types, which are daily consumption expenditure (daily), dress expenditure (dress), food payment (food), housing expenditure (house), health care expenditure (med), transportation and communication expenditure (trco), cultural and educational entertainment (eec) and other expenses (other). Combining the CFPS survey data, this article classifies the first four types of expenditure as basic consumption (Nec), and the last four types of expenditure as high-level consumption (Dev). The total household consumption is the sum of these eight types of consumption (C).

Second, the independent variable is housing price (HP). It is calculated by dividing the current market price of the current house $(\mathrm{CNY})$ and the housing area (square meters) reported in the CFPS.

Last, control variables include family income (Income), family size (FS), number of houses $(\mathrm{N})$ and head of household.

Among them, the income data in the CFPS database includes five types of operating income, property income, transfer income, wage income and other income. The variable family income (Income) is the sum of these five kinds of income. In addition, the CFPS does not include the head of the household index, and CFPS (2010) did not publish the name of the family member on the proper- 
ty certificate, so this article uses the family principal as the head of the household in 2010, and the member on the property certificate as the 2012-2018 head of household. Specifically, household head variable includes: Gender (male $=1$, female $=0$ ); Marriage (Married $=1$, otherwise $=0$ ); Age of the head of the household (Age); Years of education (Edu); Health ("very healthy", "very healthy", "relatively healthy" and "average" = 1, and "relatively unhealthy", "unhealthy" and "very unhealthy" =0);Working condition (Work) (having a job = 1 , having no job $=0)(4)$ The intermediary variable is property income (Property). The variable descriptive statistics are shown in Table 1.

\subsection{Sample Selection}

This article selects the macro data in this paper are from the website of the National Bureau of Statistics (http://www.stats.gov.cn), while the micro household data are from the China Family Panel Studies (CFPS) database. The CFPS database includes five databases, covering three levels of individuals which are level of adults and children, level of families, and level of communities. It can provide sufficient sample data for the empirical analysis. For the purpose of this paper, household samples of CFPS in 2010, 2012, 2014, 2016 and 2018 are selected to construct a five-period non-equilibrium panel data. Different from the previous scholars using short-term data, such as Wang (2016) using only one period of data and Huang \& $\mathrm{Tu}$ (2009) using three periods of data, the panel with

Table 1. Variable descriptive statistics.

\begin{tabular}{cccccc}
\hline Variable & Obs & Mean & SD & Min & Max \\
\hline C & 10,185 & $25,170.17$ & $21,327.63$ & 1934.27 & 124,000 \\
Nec & 10,185 & $16,406.88$ & $14,020.44$ & 1087.18 & $83,198.77$ \\
Dev & 10,185 & 8646.441 & 9900.457 & 171.09 & $58,806.21$ \\
HP & 10,185 & 2817.955 & 5242.793 & 20.33 & $30,965.38$ \\
Income & 10,185 & $49,832.36$ & $43,874.86$ & 4082.525 & 264,000 \\
N & 10,185 & 1.197 & 0.483 & 1 & 12 \\
FS & 10,185 & 3.884 & 1.729 & 1 & 17 \\
Age & 10,185 & 49.954 & 13.186 & 16 & 1 \\
Gender & 10,185 & 0.676 & 0.468 & 0 & 1 \\
Edu & 10,185 & 6.784 & 4.386 & 0 & 22 \\
Marriage & 10,185 & 0.946 & 0.227 & 0 & 1 \\
Work & 10,185 & 0.607 & 0.489 & 0 & 1 \\
Health & 10,185 & 0.844 & 0.363 & 0 & 1 \\
Property & 10,185 & 6912.09 & $17,358.76$ & 816.505 & 1 \\
\hline & & & & 0.656 & \\
\hline
\end{tabular}


a longer time dimension is adopted in this paper to effectively improve the accuracy of empirical estimation results.

The sample data processing steps are as follows: 1) Remove the samples without reporting the current market price of the house and the current housing area; 2$)$ calculate the housing price $\left.\left(\mathrm{CNY} / \mathrm{m}^{2}\right) ; 3\right)$ In order to effectively avoid the empirical impact of factors such as price and inflation, the 2009 household consumer price index (CPI) was used as the base period to deflate household consumption, household income and housing prices and the logarithmic treatment was performed; 4) Data with missing value and income less than consumption are excluded; 5) Winsorize tail reduction method was used for outliers. That is to replace the values outside $1 \%$ - 99\% with the quantile values of $1 \%$ and $99 \%$ for the sample data of consumption, income and housing price. Finally, 10,185 sample data are obtained as the empirical object of this paper.

\section{Empirical Results and Analysis}

\subsection{The Overall Effect}

In order to study the impact of housing price fluctuations on total household consumption and further study the differential impact of housing prices on consumption at different levels, this paper uses housing prices as the core independent variable on the basis of model (1), and takes total household consumption, basic consumption, and high-level consumption as the core dependent variables respectively, considering the control variables of household micro-features at the same time. This paper sets the model as a fixed-effect model for regression. Through the F test and Hausman test on the model (1) of total household consumption, the rationality of the basic model set in this paper is confirmed. The results in the first column of Table 2 shows that the F-test rejects the mixedeffects model at a $1 \%$ significance level. In addition, the Hausman test rejects the random-effects model at a $1 \%$ significance level, which indicates that the fixedeffect model is set in this paper is reasonable.

First, according to the regression results in the first column of Table 2, overall, the housing price has a significant positive impact on household consumption. The elasticity coefficient of housing price to consumption is 0.07 , which means that when the housing price rises by $1 \%$, the total household consumption will rise by $7 \%$. At the same time, family income, number of houses, family size and male head of household all have a significant promoting effect on household consumption. The explanation for this is as follows. Through the wealth effect, when the house price keeps rising, it means that the asset value, the wealth level and the expected income will increase, so the consumption level of households with houses will increase. Through the optimistic expectation effect, people will think psychologically that the rise of house price increases their wealth, so to some extent, household consumption will also be affected by this optimistic expectation effect. Through the liquidity constraint effect, with the rise of housing prices, homeowners can obtain the housing proceeds through various means, 
Table 2. The overall effect of housing price on consumption.

\begin{tabular}{|c|c|c|c|}
\hline Variable & (1) $\mathrm{C}$ & (2) Nec & (3) Dev \\
\hline LnHP & $\begin{array}{c}0.070^{* * *} \\
(5.97)\end{array}$ & $\begin{array}{c}0.080^{* * *} \\
(5.62)\end{array}$ & $\begin{array}{c}0.067^{* * *} \\
(3.22)\end{array}$ \\
\hline LnIncome & $\begin{array}{c}0.484^{* * *} \\
(23.01)\end{array}$ & $\begin{array}{c}0.511^{\star * *} \\
(21.76)\end{array}$ & $\begin{array}{c}0.391^{* * *} \\
(11.67)\end{array}$ \\
\hline $\mathrm{N}$ & $\begin{array}{c}0.109^{\star \star \star} \\
(4.83)\end{array}$ & $\begin{array}{c}0.107^{\star \star *} \\
(3.55)\end{array}$ & $\begin{array}{c}0.114^{\star *} \\
(2.58)\end{array}$ \\
\hline FS & $\begin{array}{c}0.070^{* * *} \\
(4.81)\end{array}$ & $\begin{array}{c}0.048^{* * *} \\
(2.99)\end{array}$ & $\begin{array}{c}0.128^{\star * *} \\
(4.87)\end{array}$ \\
\hline Age & $\begin{array}{l}0.002 \\
(1.34)\end{array}$ & $\begin{array}{c}0.005^{\star *} \\
(2.58)\end{array}$ & $\begin{array}{c}-0.005^{\star} \\
(-1.76)\end{array}$ \\
\hline Gender & $\begin{array}{c}0.059^{\star *} \\
(2.40)\end{array}$ & $\begin{array}{c}0.085^{* * *} \\
(2.96)\end{array}$ & $\begin{array}{l}0.023 \\
(0.56)\end{array}$ \\
\hline Edu & $\begin{array}{l}0.001 \\
(0.49)\end{array}$ & $\begin{array}{l}-0.001 \\
(-0.47)\end{array}$ & $\begin{array}{l}0.006 \\
(1.61)\end{array}$ \\
\hline Marriage & $\begin{array}{l}-0.119 \\
(-1.34)\end{array}$ & $\begin{array}{l}-0.135 \\
(-1.39)\end{array}$ & $\begin{array}{l}-0.048 \\
(-0.35)\end{array}$ \\
\hline Work & $\begin{array}{l}0.040 \\
(1.52)\end{array}$ & $\begin{array}{c}0.093^{* * *} \\
(3.08)\end{array}$ & $\begin{array}{l}0.001 \\
(0.03)\end{array}$ \\
\hline Health & $\begin{array}{l}-0.042 \\
(-1.34)\end{array}$ & $\begin{array}{l}-0.005 \\
(-0.13)\end{array}$ & $\begin{array}{c}-0.124^{\star *} \\
(-2.40)\end{array}$ \\
\hline Constant & $\begin{array}{c}3.825^{\star * *} \\
(15.92)\end{array}$ & $\begin{array}{c}2.912^{* * *} \\
(10.87)\end{array}$ & $\begin{array}{c}3.627^{\star *} \\
(9.21)\end{array}$ \\
\hline $\mathrm{Ob}$ & 10,185 & 10,185 & 10,185 \\
\hline $\mathrm{R}^{2}$ & 0.306 & 0.278 & 0.110 \\
\hline Fixed effect & Yes & Yes & Yes \\
\hline F-test & $\begin{array}{c}1.22 \\
(0.0000)\end{array}$ & $\begin{array}{c}1.21 \\
(0.0000)\end{array}$ & $\begin{array}{c}1.51 \\
(0.0000)\end{array}$ \\
\hline Hausman test & $\begin{array}{c}150.12 \\
(0.0000)\end{array}$ & & \\
\hline
\end{tabular}

Note: 1$)^{* * *}, * *$, and $*$ are significant at the levels of $0.01,0.05$, and 0.1 , respectively; 2) F-test and Hausman test are the $\mathrm{p}$-values in parentheses, and the rest of the brackets are the values of the statistic $t$.

such as mortgage or sale of housing, which reduces the liquidity constraint of households and significantly increase household wealth and household consumption expenditure. Through the precautionary saving effect, the rise of house price makes the household's wealth increase, so the household will reduce the precautionary saving and increase the consumption level. In addition, Huang \& $\mathrm{Tu}$ (2009) believed that through the demonstration effect, the increase of household consumption could further trigger other families to increase their consumption level, thus the overall household consumption level will be improved. Therefore, it can be verified that the increase of house price can significantly promote the increase of consumption of households with houses. 


\subsection{The Heterogeneous Effect: Different Income}

Consumer behavior varies across income groups, with high-income households less likely to cut back on spending to buy a home and low-income household less likely to cut back. In order to test the differences in the impact of different income differences on consumption, according to the quartile of household income, the sample data are divided into the following four groups of households: $0 \%-25 \%, 25 \%-50 \%, 50 \%-75 \%$ and $75 \%-100 \%$.

As it can be seen from the regression results in Table 3, for households with income levels between $50 \%-100 \%$ the housing price has a significant promotion effect on consumption. As the housing price increases by $1 \%$, the consumption will increase by $5.9 \%$ and $12.5 \%$ respectively, while the housing price increase has no significant effect on the consumption of households with income levels between $0 \%-50 \%$. This is because households with income levels between $50 \%$ and $100 \%$ belong to high-income households. On the one hand, high-income

Table 3. The heterogeneous effect: different income.

\begin{tabular}{|c|c|c|c|c|}
\hline Variable & (1) $0 \%-25 \%$ & (2) $25 \%-50 \%$ & (3) $50 \%-75 \%$ & (4) $75 \%-100 \%$ \\
\hline LnHP & $\begin{array}{l}0.028 \\
(1.00)\end{array}$ & $\begin{array}{l}0.032 \\
(1.00)\end{array}$ & $\begin{array}{c}0.059^{\star *} \\
(2.19)\end{array}$ & $\begin{array}{c}0.125^{\star * *} \\
(3.43)\end{array}$ \\
\hline LnIncome & $\begin{array}{c}0.650^{* * *} \\
(7.69)\end{array}$ & $\begin{array}{c}0.436^{* *} \\
(2.34)\end{array}$ & $\begin{array}{l}0.449^{*} \\
(1.79)\end{array}$ & $\begin{array}{c}0.414^{* * *} \\
(5.64)\end{array}$ \\
\hline $\mathrm{N}$ & $\begin{array}{l}0.105 \\
(1.38)\end{array}$ & $\begin{array}{l}0.038 \\
(0.52)\end{array}$ & $\begin{array}{l}0.048 \\
(0.81)\end{array}$ & $\begin{array}{l}0.098^{*} \\
(1.93)\end{array}$ \\
\hline FS & $\begin{array}{c}0.093^{* *} \\
(2.55)\end{array}$ & $\begin{array}{l}-0.002 \\
(-0.03)\end{array}$ & $\begin{array}{c}0.085^{\star *} \\
(2.56)\end{array}$ & $\begin{array}{c}0.105^{* * *} \\
(3.21)\end{array}$ \\
\hline Age & $\begin{array}{l}0.002 \\
(0.28)\end{array}$ & $\begin{array}{l}0.007^{\star} \\
(1.79)\end{array}$ & $\begin{array}{l}0.001 \\
(0.21)\end{array}$ & $\begin{array}{l}0.006 \\
(1.47)\end{array}$ \\
\hline Gender & $\begin{array}{l}0.108 \\
(1.58)\end{array}$ & $\begin{array}{l}0.018 \\
(0.29)\end{array}$ & $\begin{array}{l}0.178^{*} \\
(1.94)\end{array}$ & $\begin{array}{l}-0.008 \\
(-0.11)\end{array}$ \\
\hline Edu & $\begin{array}{l}-0.001 \\
(-0.07)\end{array}$ & $\begin{array}{l}0.007 \\
(0.91)\end{array}$ & $\begin{array}{c}0.000 \\
(-0.02)\end{array}$ & $\begin{array}{l}0.002 \\
(0.35)\end{array}$ \\
\hline Marriage & $\begin{array}{l}-0.099 \\
(-0.25)\end{array}$ & $\begin{array}{c}-0.569^{* * *} \\
(-2.74)\end{array}$ & $\begin{array}{c}0.471^{\star * *} \\
(2.93)\end{array}$ & $\begin{array}{l}-0.134 \\
(-0.83)\end{array}$ \\
\hline Work & $\begin{array}{l}0.107 \\
(1.56)\end{array}$ & $\begin{array}{l}0.126^{*} \\
(1.95)\end{array}$ & $\begin{array}{l}0.002 \\
(0.03)\end{array}$ & $\begin{array}{l}0.083 \\
(1.03)\end{array}$ \\
\hline Health & $\begin{array}{l}-0.146^{*} \\
(-1.73)\end{array}$ & $\begin{array}{l}-0.118 \\
(-1.37)\end{array}$ & $\begin{array}{l}-0.026 \\
(-0.27)\end{array}$ & $\begin{array}{l}0.068 \\
(0.65)\end{array}$ \\
\hline Constant & $\begin{array}{c}2.272^{\star \star \star} \\
(2.85)\end{array}$ & $\begin{array}{c}5.121^{\star * *} \\
(2.68)\end{array}$ & $\begin{array}{l}3.779 \\
(1.43)\end{array}$ & $\begin{array}{c}3.947^{\star * *} \\
(4.73)\end{array}$ \\
\hline Obs & 2552 & 2543 & 2544 & 2546 \\
\hline R2 & 0.375 & 0.095 & 0.129 & 0.222 \\
\hline
\end{tabular}

Note: 1$)^{* * *}$, $* *$ and ${ }^{*}$ are significant at the levels of $0.01,0.05$, and 0.1 , respectively; 2 ) The brackets are the values of the statistic $t$. 
families can increase consumption through the wealth effect and liquidity constraint effect. On the other hand, high-income families have a high rate of housing ownership. They even own multiple properties, and can use multiple methods such as mortgages or real estate sales to obtain investment income, increase their wealth, and then smooth the income they get through the entire life cycle, which can significantly increase the level of household consumption.

\subsection{The Heterogeneous Effect: Different Ages}

Based on the life cycle theory, although people's income level is not high in youth, their future work income will continue to increase, so young people tend to choose to save less and consume more, or even consume in advance. In middle age, people have higher income, stable job and higher consumption. However, under the influence of traditional pension concept, middle-aged people tend to save part of their income for consumption in old age. In old age, people have no working income and consume with the wealth they saved in the past. Therefore, in different periods of life, people's consumption behavior is also different. This paper divides the sample data into three groups according to age: below 45 years old, from 45 to 64 years old, and above 64 years old. Finally, grouping regression is conducted for the sample data.

As it can be seen from the regression results in Table 4, for young families and middle-aged families, the housing price has a significant promoting effect on their consumption. With the housing price increasing by $1 \%$, the consumption of young families will increase by $7.2 \%$, and that of middle-aged families will increase by $4.5 \%$. The rise in house prices has no significant impact on the consumption of elderly households. This is because for young families, rising house prices represent an increase in property wealth, which reduces the precautionary savings of the current period and increases household consumption. For middle-aged families, they tend to have higher income, work stability, high household savings, so the prices up on middle-aged family consumption has significant positive effect. Meanwhile the middle-aged need savings for old age consumption in advance. Therefore, the positive effect of rising house prices on the consumption of middle-aged families will be weaker than that of young families. For elderly families, their consumption expenditures are stable, and they have been influenced by traditional Chinese family culture for a long time. The elderly is often willing to leave housing to future generations. Therefore, even if the housing price rises, the possibility of elderly households realizing housing assets through mortgage or sale of housing is very low. The current consumption of elderly people will not increase due to rising housing prices, which makes the impact of rising housing prices on the consumption of elderly households is not significant.

\subsection{The Heterogeneous Effect: Different Numbers of Houses}

Generally speaking, for families with a house, those with the motivation to buy a 
Table 4. The heterogeneous effect: different ages.

\begin{tabular}{|c|c|c|c|}
\hline Variable & (1) Below 45 & (2) $45-64$ & (3) Above 64 \\
\hline LnHP & $\begin{array}{c}0.072^{* * *} \\
(2.84)\end{array}$ & $\begin{array}{c}0.045^{* *} \\
(2.43)\end{array}$ & $\begin{array}{l}-0.032 \\
(-0.93)\end{array}$ \\
\hline LnIncome & $\begin{array}{c}0.571^{* * *} \\
(13.25)\end{array}$ & $\begin{array}{c}0.416^{* * *} \\
(13.81)\end{array}$ & $\begin{array}{c}0.398^{* * *} \\
(5.34)\end{array}$ \\
\hline $\mathrm{N}$ & $\begin{array}{l}0.091^{\star} \\
(1.68)\end{array}$ & $\begin{array}{c}0.097^{* * *} \\
(2.91)\end{array}$ & $\begin{array}{c}0.090^{* *} \\
(2.42)\end{array}$ \\
\hline FS & $\begin{array}{c}0.099^{* * *} \\
(2.68)\end{array}$ & $\begin{array}{c}0.065^{* * *} \\
(3.09)\end{array}$ & $\begin{array}{l}0.033 \\
(1.08)\end{array}$ \\
\hline Age & $\begin{array}{l}0.015^{* *} \\
(2.04)\end{array}$ & $\begin{array}{c}0.034^{* * *} \\
(4.83)\end{array}$ & $\begin{array}{c}0.042^{* * *} \\
(3.13)\end{array}$ \\
\hline Gender & $\begin{array}{l}0.045 \\
(0.97)\end{array}$ & $\begin{array}{l}-0.022 \\
(-0.55)\end{array}$ & $\begin{array}{l}-0.020 \\
(-0.20)\end{array}$ \\
\hline Edu & $\begin{array}{l}-0.005 \\
(-1.18)\end{array}$ & $\begin{array}{c}0.008^{* *} \\
(2.14)\end{array}$ & $\begin{array}{l}0.011 \\
(1.43)\end{array}$ \\
\hline Marriage & $\begin{array}{l}-0.095 \\
(-0.72)\end{array}$ & $\begin{array}{l}-0.054 \\
(-0.23)\end{array}$ & $\begin{array}{c}0.000 \\
(-0.12)\end{array}$ \\
\hline Work & $\begin{array}{l}0.004 \\
(0.08)\end{array}$ & $\begin{array}{l}0.037 \\
(1.00)\end{array}$ & $\begin{array}{l}0.229 \\
(1.44)\end{array}$ \\
\hline Health & $\begin{array}{l}-0.004 \\
(-0.04)\end{array}$ & $\begin{array}{l}-0.067 \\
(-1.50)\end{array}$ & $\begin{array}{l}0.039 \\
(0.46)\end{array}$ \\
\hline Constant & $\begin{array}{c}2.492^{* * *} \\
(5.09)\end{array}$ & $\begin{array}{c}2.974^{* * *} \\
(6.34)\end{array}$ & $\begin{array}{c}2.386^{* *} \\
(2.00)\end{array}$ \\
\hline Obs & 3611 & 5199 & 1375 \\
\hline R2 & 0.423 & 0.281 & 0.245 \\
\hline
\end{tabular}

Note: 1$)^{* * *}, * *$, and ${ }^{*}$ are significant at the levels of $0.01,0.05$, and 0.1 , respectively; 2 ) The brackets are the values of the statistic $t$.

house will reduce consumption and save more for the purpose of buying a house, while those without the motivation to buy a house will increase consumption due to the wealth effect. In addition, for families with multiple homes, they have little demand for housing improvement and little liquidity constraint, so they may have a strong incentive to invest and obtain asset income to promote their consumption level. Therefore, the effect of housing price on consumption may be different between one-suite households and multi-suite households. In this paper, the sample is divided into two groups according to the number of housing $(\mathrm{N})$, which are families with one house and families with multiple houses. At the same time, the variable of the number of housing $(\mathrm{N})$ is deleted based on the basic model (1), and then the group regression is performed according to the number of housing.

As it can be seen from the regression results in Table 5, the wealth effect of rising house prices is significant for families with different housing numbers. 
Table 5. The heterogeneous effect: different numbers of houses.

\begin{tabular}{|c|c|c|}
\hline Variable & (1) A houses & (2) Multiple houses \\
\hline LnHP & $\begin{array}{c}0.050^{* * *} \\
(3.67)\end{array}$ & $\begin{array}{c}0.148^{\star * *} \\
(2.98)\end{array}$ \\
\hline LnIncome & $\begin{array}{c}0.494^{* * *} \\
(20.36)\end{array}$ & $\begin{array}{c}0.431^{\star * *} \\
(4.74)\end{array}$ \\
\hline FS & $\begin{array}{l}0.040 \\
(2.27)\end{array}$ & $\begin{array}{c}0.158^{\star * *} \\
(3.02)\end{array}$ \\
\hline Age & $\begin{array}{c}0.000^{* *} \\
(0.07)\end{array}$ & $\begin{array}{l}0.003 \\
(0.44)\end{array}$ \\
\hline Gender & $\begin{array}{c}0.098^{\star * *} \\
(3.36)\end{array}$ & $\begin{array}{l}0.072 \\
(0.90)\end{array}$ \\
\hline Edu & $\begin{array}{l}0.000 \\
(0.12)\end{array}$ & $\begin{array}{l}-0.006 \\
(-0.73)\end{array}$ \\
\hline Marriage & $\begin{array}{l}-0.069 \\
(-0.61)\end{array}$ & $\begin{array}{l}-0.101 \\
(-0.40)\end{array}$ \\
\hline Work & $\begin{array}{l}0.042 \\
(1.42)\end{array}$ & $\begin{array}{l}-0.068 \\
(-0.46)\end{array}$ \\
\hline Health & $\begin{array}{c}-0.084^{\star *} \\
(-2.35)\end{array}$ & $\begin{array}{l}0.139 \\
(1.14)\end{array}$ \\
\hline Constant & $\begin{array}{c}4.153^{* * *} \\
(14.52)\end{array}$ & $\begin{array}{c}3.634^{* * *} \\
(3.36)\end{array}$ \\
\hline Observations & 8448 & 1737 \\
\hline $\mathrm{R} 2$ & 0.294 & 0.286 \\
\hline
\end{tabular}

Note: 1$)^{* * *},{ }^{* *}$, and ${ }^{*}$ are significant at the levels of $0.01,0.05$, and 0.1 , respectively; 2 ) The brackets are the values of the statistic $t$.

That is, for every $1 \%$ increase in house prices, household consumption increases by $5 \%$ and $14.8 \%$ respectively, indicating that house prices are more obvious in promoting the consumption of multi-suite families. This is because for families with multiple apartments, they can mortgage, rent and sell their houses to obtain the cash income of their housing assets through a variety of investment methods. Therefore, the rising house price has a stronger promoting effect on the consumption of families with multiple apartments.

\subsection{The Heterogeneous Effect: Different Regions}

The level of economic and financial development, the degree of social security and the degree of real estate market perfection in various regions of China are unbalanced. The residents in the eastern, central and western regions have a large gap in income level, so the housing price level and household consumption level in various regions also have great regional differences. This article uses the division of the China Health Statistical Yearbook to divide households into three groups: eastern, central and western, to study the regional differences in the im- 
pact of house prices on household consumption.

As it can be seen from the regression results in Table 6, for every $1 \%$ increase in housing price, household consumption in eastern and central regions will increase by $4.6 \%$ and $8.4 \%$ respectively, but housing price has no significant impact on household consumption in western regions. The first reason is that different regions have different preventive savings. Due to the low level of economic and financial development in the western region and the imperfect social security mechanism and low-income level, family motives for preventive savings are the lowest in the east, the second in the central region, and the highest in the western region. Therefore, the household consumption level in the western region is low. The second reason is the different levels of housing prices in different regions. Compared with the high housing prices in the eastern and central regions, the overall housing prices in the western region are relatively low, with not only a slow but small rise in housing prices, so the wealth effect of housing

Table 6. The heterogeneous effect: different regions.

\begin{tabular}{|c|c|c|c|}
\hline Variable & (1) Eastern & (2) Central & (3) Western \\
\hline LnHP & $\begin{array}{c}0.046^{* *} \\
(2.10)\end{array}$ & $\begin{array}{c}0.084^{* * *} \\
(3.34)\end{array}$ & $\begin{array}{l}0.031 \\
(1.27)\end{array}$ \\
\hline LnIncome & $\begin{array}{c}0.452^{\star \star \star} \\
(15.41)\end{array}$ & $\begin{array}{c}0.326^{\star * *} \\
(8.18)\end{array}$ & $\begin{array}{c}0.432^{\star * *} \\
(10.30)\end{array}$ \\
\hline $\mathrm{N}$ & $\begin{array}{c}0.121^{\star \star \star} \\
(3.48)\end{array}$ & $\begin{array}{l}0.106^{\star} \\
(1.94)\end{array}$ & $\begin{array}{l}0.096 \\
(1.40)\end{array}$ \\
\hline FS & $\begin{array}{c}0.061^{* *} \\
(2.09)\end{array}$ & $\begin{array}{l}0.134 \\
(4.12)\end{array}$ & $\begin{array}{l}0.052 \\
(1.49)\end{array}$ \\
\hline Age & $\begin{array}{l}0.004 \\
(1.32)\end{array}$ & $\begin{array}{l}0.007 \\
(1.55)\end{array}$ & $\begin{array}{l}0.003 \\
(0.66)\end{array}$ \\
\hline Gender & $\begin{array}{c}0.090^{* *} \\
(2.01)\end{array}$ & $\begin{array}{l}0.042 \\
(0.86)\end{array}$ & $\begin{array}{l}0.012 \\
(0.18)\end{array}$ \\
\hline Edu & $\begin{array}{l}-0.002 \\
(-0.52)\end{array}$ & $\begin{array}{l}-0.005 \\
(-0.92)\end{array}$ & $\begin{array}{l}-0.007 \\
(-1.14)\end{array}$ \\
\hline Marriage & $\begin{array}{l}-0.094 \\
(-0.70)\end{array}$ & $\begin{array}{l}-0.261 \\
(-1.02)\end{array}$ & $\begin{array}{l}-0.016 \\
(-0.08)\end{array}$ \\
\hline Work & $\begin{array}{l}-0.030 \\
(-0.63)\end{array}$ & $\begin{array}{l}0.118^{\star} \\
(1.88)\end{array}$ & $\begin{array}{l}0.084 \\
(1.34)\end{array}$ \\
\hline Health & $\begin{array}{l}-0.020 \\
(-0.34)\end{array}$ & $\begin{array}{l}-0.084 \\
(-1.35)\end{array}$ & $\begin{array}{l}0.072 \\
(0.97)\end{array}$ \\
\hline Constant & $\begin{array}{c}4.343^{\star * *} \\
(12.09)\end{array}$ & $\begin{array}{c}5.097^{\star * *} \\
(10.16)\end{array}$ & $\begin{array}{c}4.472^{\star * *} \\
(8.80)\end{array}$ \\
\hline Obs & 4384 & 3168 & 2633 \\
\hline $\mathrm{R} 2$ & 0.244 & 0.202 & 0.222 \\
\hline
\end{tabular}

Note: 1$)^{* * *},{ }^{* *}$, and ${ }^{*}$ are significant at the levels of $0.01,0.05$, and 0.1 , respectively; 2 ) The brackets are the values of the statistic $t$. 
prices in the western region is not obvious. The third reason is that the financial market system in western China is not perfect and the housing market has a low level of development, which makes it difficult for homeowners in western China to realize their housing assets and gain the wealth effect of rising housing prices. Therefore, the rise of housing price does not have a significant wealth effect on household consumption in western China.

Furthermore, the sensitivity coefficient of residents' income in eastern and central regions is 0.452 and 0.326 respectively, indicating that the income sensitivity coefficient of families in eastern regions is higher than that of families in central regions. This is because for the central region, family income sources are extensive. At the same time, in the face of larger liquidity constraints and uncertainty, the central region family in order to prevent risks, will choose to more income to savings, so the central region residents income elasticity coefficient is smaller. The household income level in the eastern region is relatively high, far exceeding the overall average level. After their income minus the most basic living consumption expenditure, a portion of their income can still be left to cope with future uncertainties. Therefore, when household disposable income in the eastern region increases, they will hope to increase the spiritually higher level of enjoyment and increase other consumption expenditures. As a result, the income sensitivity coefficient of households in the eastern region is greater than the income sensitivity coefficient of households in the central region.

\subsection{Mediating Effect Test}

The housing price can not only directly promote the increase of household consumption, but also indirectly affect consumption through the change of property income. First, fluctuations in house prices will increase the rate of return on assets such as rent, increase the income of households from buying and selling housing assets, and increase the confidence of households in asset appreciation, which will increase residents' property income. Then, increased property income increases household consumption through the wealth effect. Therefore, the change of housing price may first cause the change of property income, and then affect the change of household consumption. In this case, the intermediary variable is property income variable.

The mediation effect test model is constructed as follows:

$$
\begin{aligned}
\operatorname{LnC}_{i, t}=\alpha_{0} & +\alpha_{1} \operatorname{LnHP}_{i, t}+\alpha_{2} \text { LnIncome }_{i, t}+\sum \alpha_{k} X_{k, i, t}+u_{i}+v_{t}+\varepsilon_{i, t} \\
\text { LnProperty }_{i, t}= & \beta_{0}+\beta_{1} \operatorname{LnHP}_{i, t}+\beta_{2} \text { LnIncome }_{i, t}+\sum \beta_{k} X_{k, i, t}+u_{i}+v_{t}+\varepsilon_{i, t} \\
\operatorname{LnC}_{i, t}= & \gamma_{0}+\gamma_{1} \operatorname{LnHP}_{i, t}+\gamma_{2} \text { LnProperty }_{i, t}+\gamma_{3} \text { LnIncome }_{i, t} \\
& +\sum \gamma_{k} X_{k, i, t}+u_{i}+v_{t}+\varepsilon_{i, t}
\end{aligned}
$$

The specific test steps of mediating effect are as follows: 1) Centralize all variables; 2) If $\alpha_{1}$ is significant, enter step 3, otherwise stop testing; 3) If both $\beta_{1}$ and $\gamma_{2}$ are significant, the mediating effect test is passed. If $\gamma_{1}$ is not significant 
particularly, it is a complete mediator. If at least one of $\beta_{1}$ and $\gamma_{2}$ tests is not significant, the test is weak, and it is likely to make the second type of error, so enter step 4; 4) Sobel (1982) test. If the Sobel test results are significant, it will pass the intermediate test. Otherwise, it will end without passing the test.

Test results are shown in Table 7. In the model (2), $\alpha_{1}$ is significant, indicating that house prices have a significant positive effect on household consumption. In model (3), $\beta_{1}$ is significant, suggesting that impact of house price changes on household property income is significantly positive. In the model (4), $\gamma_{1}$ and $\gamma_{2}$ are significant, showing that price changes affect household consumption is partly due to the family property income variable. Thus, the property income is the partial mediation.

Table 7. Mediating effect test.

\begin{tabular}{|c|c|c|c|}
\hline Variable & Model (2) & Model (3) & Model (4) \\
\hline LnHP & $\begin{array}{c}0.055^{\star * *} \\
(4.03)\end{array}$ & $\begin{array}{c}0.070^{* * *} \\
(12.09)\end{array}$ & $\begin{array}{c}0.036^{\star * *} \\
(2.13)\end{array}$ \\
\hline LnIncome & & & $\begin{array}{c}0.016^{* * *} \\
(9.57)\end{array}$ \\
\hline $\ln Y$ & $\begin{array}{c}0.408^{\star * *} \\
(19.49)\end{array}$ & $\begin{array}{c}0.105^{\star * *} \\
(12.43)\end{array}$ & $\begin{array}{c}0.349^{* * *} \\
(16.85)\end{array}$ \\
\hline $\mathrm{N}$ & $\begin{array}{c}0.117^{\star * *} \\
(4.33)\end{array}$ & $\begin{array}{c}0.048^{\star * *} \\
(3.27)\end{array}$ & $\begin{array}{c}0.098^{* * *} \\
(3.73)\end{array}$ \\
\hline FS & $\begin{array}{c}0.084^{\star * *} \\
(4.45)\end{array}$ & $\begin{array}{c}-0.022^{\star * *} \\
(-2.64)\end{array}$ & $\begin{array}{c}0.095^{\star * *} \\
(4.99)\end{array}$ \\
\hline Age & $\begin{array}{l}0.004^{*} \\
(1.96)\end{array}$ & $\begin{array}{c}0.009^{* * *} \\
(7.79)\end{array}$ & $\begin{array}{c}0.000 \\
(-0.28)\end{array}$ \\
\hline Gender & $\begin{array}{c}0.058^{*} \\
(1.95)\end{array}$ & $\begin{array}{c}0.062^{\star * *} \\
(4.36)\end{array}$ & $\begin{array}{l}0.038 \\
(0.97)\end{array}$ \\
\hline Edu & $\begin{array}{l}-0.004 \\
(-1.30)\end{array}$ & $\begin{array}{c}-0.010^{\star * *} \\
(-9.07)\end{array}$ & $\begin{array}{l}0.002 \\
(0.35)\end{array}$ \\
\hline Marriage & $\begin{array}{l}-0.114 \\
(-1.05)\end{array}$ & $\begin{array}{c}-0.224^{* * *} \\
(-3.94)\end{array}$ & $\begin{array}{l}-0.006 \\
(-0.04)\end{array}$ \\
\hline Work & $\begin{array}{l}0.046 \\
(1.39)\end{array}$ & $\begin{array}{c}0.096^{* * *} \\
(7.59)\end{array}$ & $\begin{array}{l}-0.002 \\
(-0.04)\end{array}$ \\
\hline Health & $\begin{array}{l}-0.018 \\
(-0.48)\end{array}$ & $\begin{array}{l}-0.004 \\
(-0.36)\end{array}$ & $\begin{array}{l}-0.036 \\
(-0.44)\end{array}$ \\
\hline Constant & $\begin{array}{l}0.000^{* * *} \\
(-17.17)\end{array}$ & $\begin{array}{l}0.000^{* * *} \\
(-242.66)\end{array}$ & $\begin{array}{c}0.000^{* * *} \\
(6.49)\end{array}$ \\
\hline Observations & 10,185 & 10,185 & 10,185 \\
\hline $\mathrm{R}^{2}$ & 0.217 & 0.399 & 0.259 \\
\hline
\end{tabular}

Note: 1$)^{* * *}{ }^{* *}$, and ${ }^{*}$ are significant at the levels of $0.01,0.05$, and 0.1 , respectively; 2 ) The brackets are the values of the statistic $t$. 


\subsection{Robustness Test}

Based on the fixed-effect model, this paper empirically analyzes the impact of housing price on household consumption, and the results show that the rise of housing price has a significant positive impact on household consumption. To further examine the reliability of the regression results of the benchmark model (1), the robustness test of the benchmark model (1) was performed by replacing the total household consumption (C) with the average household consumption tendency (APC). From the results of regression in Table 8, the positive effect of house prices on household consumption is very stable.

\section{Research Conclusion and Policy Recommendations}

This article selects data from five periods of the CFPS in the year of 2010,2012, 2014, 2016 and 2018 to construct an unbalanced short panel. Meanwhile, it uses a fixed effect model to empirically study the overall effect of the housing price on

Table 8. Robustness test.

\begin{tabular}{|c|c|}
\hline Variable & APC \\
\hline LnHP & $\begin{array}{c}0.027^{* * *} \\
(4.90)\end{array}$ \\
\hline LnIncome & $\begin{array}{c}0.218^{* * *} \\
(24.30)\end{array}$ \\
\hline $\mathrm{N}$ & $\begin{array}{c}0.049^{* * *} \\
(4.49)\end{array}$ \\
\hline FS & $\begin{array}{c}0.032^{\star * *} \\
(5.18)\end{array}$ \\
\hline Age & $\begin{array}{c}0.002^{\star *} \\
(1.97)\end{array}$ \\
\hline Gender & $\begin{array}{c}0.031^{\star * *} \\
(2.79)\end{array}$ \\
\hline Edu & $\begin{array}{l}-0.001 \\
(-0.73)\end{array}$ \\
\hline Marriage & $\begin{array}{l}-0.042 \\
(-1.04)\end{array}$ \\
\hline Work & $\begin{array}{l}0.021^{\star} \\
(1.71)\end{array}$ \\
\hline Health & $\begin{array}{l}-0.013 \\
(-0.88)\end{array}$ \\
\hline Constant & $\begin{array}{c}2.443^{* * *} \\
(23.19)\end{array}$ \\
\hline Observations & 10185 \\
\hline $\mathrm{R}^{2}$ & 0.241 \\
\hline
\end{tabular}

Note: 1$)^{* * *},{ }^{* *}$, and ${ }^{*}$ are significant at the levels of $0.01,0.05$, and 0.1 , respectively; 2 ) The brackets are the values of the statistic $t$. 
consumption and the effect of different consumption levels. Then, the heterogeneous effect of the family income, ages of the head of the household, the numbers of houses and regions are analyzed. Finally, the transmission mechanism of this effect is further investigated. This article has the following main conclusions: 1) The housing price has a positive impact on the consumption of households with houses. At the same time, the elasticity coefficient of the housing price on the basic consumption is greater than that of the high-level consumption, indicating that the housing price has a stronger promoting effect on the basic consumption. So, the housing price can promote the upgrading of household consumption. 2) The housing price mainly affects the consumption of young or middle-aged households with high income. The housing price has a significant positive effect on both one-suite and multi-suite families, but has a stronger effect on the consumption of multi-suite families. The housing price has a significant positive influence on the household consumption in eastern and central regions, but the rising housing price has no significant influence on the household consumption in western regions. 3) The impact of house prices on consumption is partially transmitted through property income, and the wealth effect of housing price is obvious.

Based on the above conclusions, this article proposes the following policy recommendations: 1) Improve the housing and financial markets, and play the role of channels. Since the current Chinese residents mainly obtain property income through house leasing, bank interest and securities investment, the government and enterprises need to jointly improve the housing and financial market, and the regulatory unit needs to build an online platform for the secondary market. What's more, the housing intermediary company needs to build an online service platform and the financial sector needs to innovate financial instruments in the real estate market and increase the size of housing loans to better play the role of these channels. 2) Implement differentiated policies and narrow the income gap. Because the wealth effect is different in terms of household income, age of the head of household, number of houses and region, differentiated housing policies and loan policies should be implemented to encourage different regions to develop the economy according to local conditions. It is necessary to increase financial investment, implement policy tilts in underdeveloped areas, severely crack down on speculation in real estate speculation, and at the same time improve income distribution and social security systems to narrow the income gap between residents. What's more, to improve the spending of the young married couples and low-income families, when they buy their first home, especially affordable housing, the banking department should reduce the down payment ratio. However, for families with high incomes and multiple suites, the banking department can appropriately increase the difficulty of lending to them, or even refuse to issue housing loans, while improving the down payment ratio. This can effectively reduce the speculation of multi-suite families, better limit the rate and extent of house prices, and stimulate household consumption. 3) 
Guide the change of consumption concept and give play to the wealth effect. Under the long-term influence of traditional consumption concepts and old-age care concepts, many families in China are reluctant to consume in advance through loans and housing mortgages, which has largely suppressed the wealth effect of house prices. Therefore, government departments should gradually weaken the capital goods attribute of real estate, emphasizing its attribute of consumer goods, support homeless loans to buy a house, support homeowners to obtain liquidity funds through housing mortgage loans and other means, and actively guide and nurture the consumption concept of elderly residents. This will fully release the wealth effect of housing and increase domestic consumer demand.

\section{Conflicts of Interest}

The authors declare no conflicts of interest regarding the publication of this paper.

\section{References}

Barrell, R., Costantini, M., \& Meco, I. (2015). Housing Wealth, Financial Wealth, and Consumption: New Evidence for Italy and the UK. International Review of Financial Analysis, 42, 316-323. https://doi.org/10.1016/j.irfa.2015.08.007

Bhatia, K., \& Mitchell, C. (2015). Household-Specific Housing Capital Gains and Consumption: Evidence from Canadian Microdata. Regional Science and Urban Economics, 56, 19-33. https://doi.org/10.1016/j.regsciurbeco.2015.10.004

Gan, J. (2010). Housing Wealth and Consumption Growth: Evidence from a Large Panel of Households. Review of Financial Studies, 23, 2229-2267. https://doi.org/10.1093/rfs/hhp127

Gao, L. L., \& Zhou, H. D. (2013).Structural Change and Technical Progress in Region Economic Growth: Evidence from China. Scientific Decision-Making, 12, 16-26.

Hu, Y. Z., \& Yuan, Y. F. (2017). The Effect of House Prices on Consumption in China. China Economic Quarterly, 16, 1031-1050.

Huang, J., \& Tu, M. Z. (2009). The Real Estate Wealth and Consumption: Evidences from the Data from Micro-Investigations of Families. Management World, 7, 35-45.

Karl, E. C., John, M. Q., \& Robert, J. S. (2012) Wealth Effects Revisited 1975-2012. Cowles Foundation Discussion Papers, 2, 101-128. https://doi.org/10.1561/104.00000009

Li, J. (2015). Housing Assets, Price Fluctuations and Chinese Urban Residents' Consumption Behavior-Analysis Based on Transmission Channels. Journal of Finance and Economics, 8, 91-105.

Li, J., \& Zang, X. H. (2015). Housing Price Fluctuation and Consumer Behavior of Chinese Urban Residents-Based on the Analysis of Provincial Dynamic Panel Data from 2004 to 2011. Nankai Economic Studies, 1, 89-101.

Wang, Y. (2016). The Regional Heterogeneous Effect of Housing Prices Fluctuation on Homeowners Consumption. Journal of Applied Statistics and Management, 36, 402-418.

Yi, X. J., Zhang, B., \& Yang, B. Y. (2011). An Empirical Study on the Strength of Precautionary Savings Motive of Urban Inhabitants in China. Journal of Shanghai University of Finance and Economics, 13, 50-58.

Zhang, T. T., \& Sun, P. Y. (2019). Tariff Transmission, Housing Prices and Market Consumer Prices: An Analysis Based on the Micro Price Perspective. Journal of Finance and Economics, $45,46-58+72$. 